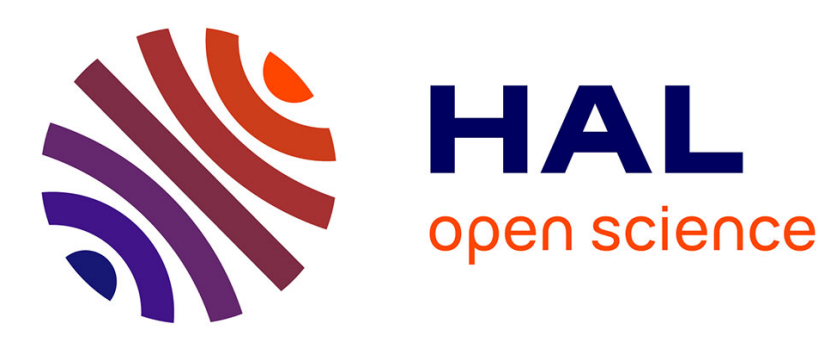

\title{
TWO-WAVELENGTH DYE LASER FOR APPLICATION IN PDT METHOD TREATMENT OF CANCER
}

L. Pokora, Z. Puzewicz

\section{- To cite this version:}

L. Pokora, Z. Puzewicz. TWO-WAVELENGTH DYE LASER FOR APPLICATION IN PDT METHOD TREATMENT OF CANCER. Journal de Physique IV Proceedings, 1991, 01 (C7), pp.C7268-C7-268. 10.1051/jp4:1991773 . jpa-00251016

\section{HAL Id: jpa-00251016 https://hal.science/jpa-00251016}

Submitted on 1 Jan 1991

HAL is a multi-disciplinary open access archive for the deposit and dissemination of scientific research documents, whether they are published or not. The documents may come from teaching and research institutions in France or abroad, or from public or private research centers.
L'archive ouverte pluridisciplinaire HAL, est destinée au dépôt et à la diffusion de documents scientifiques de niveau recherche, publiés ou non, émanant des établissements d'enseignement et de recherche français ou étrangers, des laboratoires publics ou privés. 


\title{
TWO-WAVELENGTH DYE LASER FOR APPLICATION IN PDT METHOD TREATMENT OF CANCER
}

L. POKORA and Z. PUZEWICZ

Institute of Quantum Electronics, Kaliski St. 6, PL-01-489 Warsaw, Poland

\begin{abstract}
The construction and basic characteristics of two-wavelength dye laser system purposely constructed for dianosis and treatment of cancer using PDT method e.g.[1,2] with hematopomphyin derivative (Hpd) has been presented. The requirements for this construction have been worked out on the basis of principle literature $[2,3]$ and of polish investigations e.g. [4] in the PDT method.

Oux dye laser is a generator of $405 \mathrm{~nm}$ or $630 \mathrm{~nm}$ wavelength radiation. The wavelength $405 \mathrm{~nm}$ is diagnosis 1 ine and $630 \mathrm{~nm}$ is the therapy one. In our system it ia gained through excitation by an excimer laser radiation [5] of one of LC4090 or LC5400 dyes alternately plased in a stable resonator of the laser dye. The resonator has an output dielectric mirror with two maxima (for 405 and $630 \mathrm{~nm}$ ) in $1 \mathrm{tg}$ transmision characteriatic. The dyes are placed in a double dye cell. In one part of the celi there 13 LC4090 dye dissolved in dioxan whlle in the other one Rhodamine 101 (LC6400) dissolved in etanol. The "up and down" change of the celi position in the resonator is done mechanicaliy, quaranteeing the generation 18 approximately the same and reaches $10 \%$. The solution of both dyes of 0.2511 tre volume are placed in cooled reservolra. They are pumped to the respective cel1's using wave-pumps. The basic characteristics of our dye laser have been presented.
\end{abstract}

References:

[1]. T.J.Dougherty, J.E.Kaufman et al, Cancer Res,,38,2628,1978

[2]. T.Hirano, M. I shizuka et al. Lasers in the Life sciences $3(2), \mathrm{p} .99,1989$

[3]. Y.Hayata, T.J.Dougherty, "Lasers and Hematoporphyrin", Publ. by IGAKU SHOIH Ltd., Tokyo, 1983

[4]. J.Konargk1, M.Kwasny, A.Graczyk, Proc, SPIE, 859, 227, 1988

[5]. L.Iwanejko, L, Pokora, Proc, of SPIE, 1391, 38, 1991 